\title{
APLIKASI MODEL OREM DALAM MENINGKATKAN KETERAMPILAN IBU DALAM TEHNIK MENYUSUI BAYI DI PKM KARANG TALIWANG MATARAM NTB
}

\author{
Mardiatun $^{1}$, Dewi Purnamawati ${ }^{2}$ Aan Dwi Sentana ${ }^{3}$ \\ 1,2,3 Jurusan Keperawatan, Poltekkes Kemenkes Mataram, Indonesia
}

\begin{abstract}
Abstrak
Menyusui merupakan proses yang alami, namun demikian, menyusui perlu di pelajari antara lain, belajar bagaimana cara memegang bayi agar dapat menyusu dengan baik dan mengatur posisi tubuh agar merasa nyaman selama menyusui. Seringkali kegagalan menyusui disebabkan karena kesalahan memposisikan dan melekatkan bayi. Putting susu menjadi lecet sehingga ibu jadi segan menyusui, produksi ASI berkurang dan bayi menjadi malas menyusu. Tujuan penelitian ini adalah Menganalisis pengaruh Penerapan Aplikasi Model Orem dapat Meningkatkan Keterampilan Ibu Dalam Teknik Menyusui Bayi Instrumen yang digunakan pada penelitian ini adalah dengan menggunakan buku panduan yang di buat peneliti di PKM Karang Taliwang-Mataram NTB. Penelitian ini menggunakan jenis penelitian Quasy eksperiment dengan pretest posttest group design dan menggunakan instrument berupa kuesioner dan lembar observasi checklist. Analisa statistik yang digunakan dengan menggunakan Uji Paired t test dengan taraf signifikasi $\mathrm{p}<0,05$ untuk melihat perbedaan pre dan post keterampilan menyusui pada kelompok perlakuan dan Kontrol dan uji Independent $t$ test dengan taraf signifikansi $\mathrm{p}<0,05$ untuk melihat perubahan keterampilan menyusui setelah di berikan pendekatan Aplikasi Model Orem. Hasil yang didapatkan P value $0.000<0,005$ ada perbedaan keterampilan menyusui pada kelompok perlakuan dan kelompok kontrol dengan tarap signifikansi $\mathrm{p}$ value $0.001<0,05$ ada perubahan keterampilan menyusui setelah pendekatan aplikasi model Orem dengan tarap signifikansi $\mathrm{p}$ value $0.001<0,05$. Dari hasil penelitian dapat disimpulkan dan disarakan perlunya model pendekatan yang intensif dalam mengubah perilaku ibu nifas khususnya mengenai keterampilan menyusui agar proses menyusui ibu berhasil.
\end{abstract}

\section{Kata Kunci : orem, keterampilan ibu, menyusui}

\section{Abstrak}

Breastfeeding is a natural process, however, breastfeeding needs to be learned. Several things to learn about breastfeeding including learning how to hold the baby to suckle well and adjust the position of the body to feel comfortable during breastfeeding. Oftentime, the failure in breastfeeding is caused by a wrong way in positioning and attaching the baby which can cause sore nipple and making the mothers becomes reluctant to breastfeed. Results in decrease breastmilk production and the baby becomes lazy to suckle. The purpose of this study was to analyze the effect of the application of the OREM model to improve the skills of mothers in breastfeeding techniques. The instrument used in this study was a guidebook developed by the researchers at the PKM Karang Taliwang-Mataram NTB. This study is a Quasy experiment study with pre-post test group design. Data were collected using questionnaires and checklist observation sheets. Statistical analysis used was the Paired t-test with a significance level of $p<0.05$ to see differences of mothers' breastfeeding skills on pre and post intervention in the treatment and control groups. Independent t-test with a significance level of $p<0.05$ was used to see the changes in breastfeeding skills after given the Orem Model Application approach. The results showed that with $P$ value $0.000<0.005$ there were differences in breastfeeding skills in the treatment group and the control group with a significance of 
$\mathrm{p}$ value $0.001<0.05$. There was a change in breastfeeding skills after the Orem model application approach with a significance of $p$ value $0.001<0.05$. It can be concluded and suggested the need for an intensive model approach in changing the behavior of postpartum mothers, especially regarding breastfeeding skills so that the mother's breastfeeding process is successful.

\section{Kata Kunci : OREM, Mothers, Breastfeeding}

\section{PENDAHULUAN}

Menyusui merupakan proses yang alami, namun demikian, menyusui perlu di pelajari antara lain, belajar bagaimana cara memegang bayi agar dapat menyusu dengan baik dan mengatur posisi tubuh agar merasa nyaman selama menyusui. Seringkali kegagalan menyusui disebabkan karena kesalahan memposisikan dan melekatkan bayi. Putting susu menjadi lecet sehingga ibu jadi segan menyusui, produksi ASI berkurang dan bayi menjadi malas menyusu. Acara peringatan hari ibu ke62 di Jakarta 22 Desember 1990 telah dicanangkan gerakan nasional peningkatan penggunaan ASI oleh mantan Presiden Soeharto. Dianjurkan agar ibu-ibu paling tidak agar menyusui bayinya selam 4-6 bulan dan juga bahkan agar kaum ibu mempeloporinya. Perlunya pemberian ASI pada anak sudah menjadi masalah nasional dan intemasional mengingat eratnya hubungannya dengan gizi anak.

Kondisi kesehatan ibu dan anak saat ini masih sangat penting untuk ditingkatkan serta mendapatkan perhatian yang khusus. Upaya penurunan kematian ibu dan bayi, dapat dilakukan dengan peningkatan cakupan dan kualitas pelayanan kesehatan ibu dan anak. Salah satu upaya yang dilakukan adalah dengan melakukan pembinaan kesehatan anak sejak dini melalui kegiatan kesehatan ibu dan anak, perbaikan gizi balita dan pembinaan balita agar setiap balita yang dilahirkan akan tumbuh sehat dan berkembang menjadi manusia Indonesia yang tangguh dan berkualitas. Agar dapat mempersiapkan manusia yang berkualitas tersebut, maka kita perlu memelihara gizi anak sejak bayi berada dalam kandungan. (Almatsier, 2004).

Bayi yang lahir dari ibu yang gizinya baik selain dapat tumbuh dan berkembang dengan baik juga akan memberi air susu ibu (ASI) yang cukup untuk bayinya. ASI merupakan makanan bergizi yang paling lengkap, aman, hygienis dan murah. ASI juga meningkatkan keakraban ibu dan anak yang bersifat menambah kepribadian anak dikemudian hari. Itulah sebabnya ASI terbaik untuk bayi. Dari berbagai study dan pengamatan menunjukkan bahwa dewasa ini terdapat kecenderungan penurunan penggunaan ASI dan mempergunakan pemberian ASI dengan susu fomula di masyarakat. Dengan kenaikan tingkat partisipasi wanita dalam angkatan kerja dan peningkatan sarana komunikasi dan transportasi yang memudahkan periklanan susu buatan serta luasnya distribusi susu buatan terdapat kecenderungan menurunnya kesediaan menyusui maupun lamanya menyusui baik dipedesaan dan diperkotaan. Menurunnya jumlah ibu yang menyusui sendiri bayinya pada mulanya terdapat pada kelompok ibu di kota-kota terutama pada keluarga berpenghasilan cukup yang kemudian menjalar sampai ke Desa-Desa. Meskipun menyadari 
pentingnya pemberian ASI tetapi budaya modern dan kekuatan ekonomi yang semakin meningkat telah mendesak para ibu untuk segera menyapih anaknya dan memilih air susu buatan sebagai jalan keluarnya. Meningkatnya lama pemberian ASI dan semakin meningkatnya pemberian susu botol menyebabkan kerawanan gizi pada bayi dan balita (Siregar, 2004).

Menurut WHO (2009) prevelensi ibu dan anak di dunia diperkirakan sebanyak 15,5\%, itu berarti bahwa 20,6 juta bayi yang lahir tidak mendapatkan pemberian ASI esklusif tiap tahunnya, dan 95,6\% berada dinegara berkembang. Rata-rata insidensi pemberian asi esklusif di wilanyah United Nation, dengan insidensi tertinggi di Asia tenggara $(27,1 \%)$ dan terendah di Eropa $(6,4 \%)$ (SDKI, 2009). Survei Demografi dan Kesehatan Indonesia 1997-2007 memperlihatkan terjadinya penurunan prevalensi ASI eksklusif dari 40,2\% pada tahun 1997 menjadi 39,5\% dan 32\% pada tahun 2003 dan 2007. Pemberian ASI eksklusif pada bayi selama 6 bulan di Indonesia hanya 15,3\%. Dalam penyedia layanan kesehatan pun sudah disediakan pojok ASI, klinik ASI, atau layanan sejenisnya yang bertujuan mendukung kebijakan pemberian ASI eksklusif, namun cakupan ASI ekslusip masih rendah (Riskesdas, 2010).

Masalah kesehatan anak di Indonesia masih didominasi oleh tingginya angka kematian bayi dan balita serta prevalensi balita gizi kurang. Oleh karena itu, telah ditetapkan indikator Rencana Pembangunan Jangka Menengah (RPJMN) tahun 2010 - 2014 sekaligus disesuaikan dengan target pencapaian MDGs, yaitu menurunkan Angka Kematian Bayi (AKB) dari 34/1000 menjadi 23/1000 Kelahiran Hidup dan menurunkan prevalensi gizi kurang balita menjadi $15 \%$ pada tahun 2015 .

Di Puskesmas Tanjung Karang - Mataram Propinsi NTB telah dilakukan penyuluhan kesehatan yang biasanya dilakukan secara lansung (face to face) sebelum ibu nifas dipulangkan, namun penyuluhan tersebut tidak dilakukan melalui media khusus. Penyuluhan kesehatan atau pengajaran yang dilakukan oleh tenaga kesehatan kepada pasien atau sasaran yang dikendaki tidak dapat lepas dari media karena melalui media, pesan-pesan yang disampaikan dapat lebih menarik dan dipahami, sehingga sasaran dapat mempelajari pesan tersebut sampai memutuskan untuk mengadopsi perilaku yang positif (Notoatmodjo, 2010 ). Terdapat beberapa media cetak yang dapat di gunakan dalam memberikan bimbingan dan pengajaran kepada ibu nifas yaitu leaflet, buku panduan, lembar balik (flip chart), flyer (selebaran), poster, brosur, majalah kesehatan, spanduk, booklet dll. Pemilihan booklet sebagai media dalam memberikan bimbingan dan pengajaran memiliki peran dapat memuat informasi relatif lebih banyak dan lebih spesifik serta dapat menimbulkan minat sasaran pendidikan (Sumaryati, 2003). Penggunaan buku panduan menyusui sebagai media yang informatif dapat membantu perawat atau bidan dalam memberikan bimbingan dan pengajaran tentang tehnik menyusui bayi agar tercapainya asuhan nifas yang oftimal. Hal ini dapat di berikan baik selama perawatan maupun saat ibu akan pulang sebagai bekal untuk melanjutkan asuhan nifas selama di rumah ( Maryunani, 2009 ). Pengalaman di beberapa negara di dunia bahwa peningkatan pemberian ASI ada hubungannya dengan cara-cara yang dilakukan di rumah sakit. Peranan sikap dan 
kepedulian serta perhatian para ahli kesehatan yang berkaitan dengan menyusui sangat diperlukan terutama dalam menghadapi promosi-promosi pabrik pembuat susu formula bayi. Posisi strategi dari peranan instansi kesehatan dan para tenaga kesehatan terutama di rumah sakit sangat bermanfaat bagi pelaksanaan kegiatan operational pemasyarakatan ASI.

Periode postpartum terdiri dari periode immediate postpartum, early postpartum dan late postpartum. Immediate postpartum yaitu masa segera setelah plasenta lahir sampai dengan dua puluh empat jam pertama. Periode early postpartum mulai dari dua puluh empat jam sampai satu minggu dan periode late postpartum mulai satu minggu pertama sampai lima minggu (Saleha, 2009). Pemberian beberapa informasi oleh tenaga kesehatan tentang beberapa hal penting akan lebih praktis pada masa nifas dini (Bobak, 2004), Pemilihan teori keperawatan Orem dalam penelitian ini karena focus dari teori ini lebih bertumpu pada pelayanan terapeutik yang mandiri dengan melibatkan setiap individu agar mampu melakukannya secara mandiri dan berdasarkan teori keperawatan Self Care Deficit yang dikemukakan oleh Dorothea Orem, manusia pada dasarnya mempunyai kemampuan dalam merawat dirinya sendiri. Yang dimaksud dengan self care (perawatan mandiri) adalah aktivitas seseorang untuk menolong dirinya sendiri dalam mempertahankan hidup, kesehatan dan kesejahteraan (Tommy and Alligood, 2006). Faktor pendorong (predisposing factors) gagalnya pemberian ASI Eksklusif adalah kurangnya pengetahuan subjek tentang ASI Eksklusif, sehingga tidak muncul motivasi yang kuat dari subjek untuk memberikan ASI Eksklusif pada bayinya. Faktor pemungkin (enabling factors) gagalnya pemberian ASI Eksklusif adalah kurangnya penyuluhan atau pengarahan tentang ASI Eksklusif dari Posyandu, Puskesmas (Afifah, 2007) Menurut (Ruchala et al, 2000) Persepsi tentang topik pengajaran yang paling penting menurut ibu nifas pada masa post partum yaitu prioritas pengajaran pada perawatan diri (perawatan payudara) (Cook et al, 2006). Hasil penelitian Rahayu dan Sudarmiati (2012) menunjukkan bahwa pengetahuan ibu primipara baik dan cukup baik. Namun ada ibu primipara yang memiliki pengetahuan kurang baik dan tidak baik pada teknik menyusui

Peran supportif dan edukatif perawat dibutuhkan oleh pasien yang memerlukan dukungan pendidikan dengan harapan pasien mampu melakukan tehnik menyusui yang benar. Sistem ini dilakukan agar pasien mampu melakukan tindakan keperawatan setelah dilakukan pembelajaran (Tommey and Alligood, 2006). Salah satu metoda bantuan yang diberikan menurut Orem adalah dengan memberikan Guidence and Teaching untuk memfasilitasi kemampuan klien dalam memenuhi kebutuhan secara mandiri (George, 1995) yang berguna untuk membantu proses penyelesaian masalah serta mendorong perawatan preventif (Bobak, 2004).

\section{METODE}

Desain yang digunakan dalam penelitian ini adalah Quasy ekperiment - pretest - posttest control group design. Populasi dalam penelitian ini adalah Semua ibu postpartum di PKM karang 
taliwang Mataram. Sampel pada penelitian ini adalah sebagian dari populasi yang memenuhi kriteria inklusi sebagai berikut : Ibu post partum (primipara), Ibu yang bersedia menjadi responden. Criteria ekslusi : Putting susu tidak lecet, ASI ibu tidak keluar, Ibu yang tidak ada ditempat saat penelitian atau tidak bersedia menjadi responden.

Adapun besar sampel yaitu 30 responden yang diambil secara consecutive sampling, kemudian responden dibagi 2 kelompok yaitu 15 responden sebagai kelompok perlakuan dan 15 responden sebagai kelompok kontrol. Pengumpulan data dilakukan 4 kali kelompok perlakuan dan 3 kali kelompok kontrol yaitu sebelum dan setelah perlakuan dengan menggunakan instrumen berupa lembar observasi cheklist. Analisa statistik yang digunakan dengan menggunakan uji Wilcoxon Signed Ranks dengan taraf signifikansi $\mathrm{p}<0,05$.

\section{HASIL PENELITIAN}

1. Karakteristik responden berdasarkan pendidikan, umur dan pekerjaan pada kelompok perlakuan dan kelompok kontrol di PKM Karang Taliwang Mataram

Tabel 1. Karakteristik responden berdasarkan pendidikan, umur dan pekerjaan pada kelompok perlakuan dan kelompok kontrol di PKM Karang Taliwang Mataram

\begin{tabular}{|c|c|c|c|}
\hline Karakteristik & Perlakuan $(n=15)$ & Kontrol $(n=15)$ & Harga $P$ \\
\hline $\begin{array}{l}\text { Umur } \\
\qquad \begin{array}{l}20 \text { - } 25 \text { tahun } \\
26 \text { - } 30 \text { tahun } \\
31 \text { - } 35 \text { tahun }\end{array}\end{array}$ & $\begin{array}{ll}12 & (80 \%) \\
2 & (13 \%) \\
1 & (6,7 \%)\end{array}$ & $\begin{array}{rc}10 & 66,7 \% \\
1 & 6,7 \% \\
4 & 26,7 \%\end{array}$ & 0,680 \\
\hline $\begin{array}{l}\text { Pendidikan } \\
\text { SMP } \\
\text { SMA / PT }\end{array}$ & $\begin{array}{ll}7 & 46,7 \% \\
8 & 53,3 \%\end{array}$ & $\begin{array}{rl}4 & 26,7 \% \\
11 & 73,3 \%\end{array}$ & 0,543 \\
\hline $\begin{array}{l}\text { Pekerjaan } \\
\text { IRT } \\
\text { PNS/Swasta }\end{array}$ & $\begin{array}{cl}14 & 93,3 \% \\
1 & 6,7 \%\end{array}$ & $\begin{array}{rc}13 & 86,7 \% \\
2 & 13.3 \%\end{array}$ & 0,256 \\
\hline
\end{tabular}

Berdasarkan Tabel 1 dapat diketahui bahwa kelompok umur responden terbanyak pada kelompok perlakuan sebanyak 13 orang (80\%) dan kelompok kontrol sebanyak 10 orang $(66,7$ $\%)$ adalah kelompok umur 20 - 25 tahun. Dari hasil uji $t$ didapatkan nilai p $(0,680)>0,05$ berarti tidak ada perbedaan karateristik usia responden. Pendidikan responden terbanyak baik pada kelompok perlakuan sebanyak 8 orang (53.3\%) dan pada kelompok kontrol sebanyak 11 orang $(73,3 \%)$ adalah tamat SMA/PT. Dari hasil uji $t$ didapatkan nilai p $(0,256)>0,05$ berarti tidak ada perbedaan karateristik pendidikan responden. Pekerjaan responden terbanyak pada kelompok perlakuan sebanyak 14 (93\%) dan pada kelompok kontrol sebanyak 13 (86\%) adalah Ibu Rumah Tangga (IRT). Dari hasil uji $t$ didapatkan nilai $\mathrm{p}(0,543)>0,05$. 
2. Keterampilan ibu dalam tehnik menyusui sebelum dan setelah diberikan pendekatan Supportive Educative (bimbingan dan pengajaran) pada kelompok perlakuan dan kelompok kontrol di PKM Karang Taliwang Mataram

Hasil penelitian menunjukkan bahwa dari hasil uji Paired $t$ Test diperolah nilai $\mathrm{p}$ $(0,001)<0,05$ terdapat perbedaan keterampilan menyusui responden sebelum dan setelah diberikan pendekatan Supportive Educative (bimbingan dan pengajaran) dibandingkan dengan kelompok kontrol didapatkan nilai $\mathrm{p}(0,164)>0,05$ bahwa tidak terdapat perbedaan signifikan perawatan diri responden pada saat pre dan post test pada kelompok kontrol.

Tabel 2. Keterampilan ibu dalam tehnik menyusui pre test dan post test pada kelompok perlakuan dan kelompok kontrol di Puskesmas Karang Taliwang NTB bulan Agustus - Oktober Tahun 2016.

Paired Samples Statistics

\begin{tabular}{llccccc}
\hline & & Mean & N & Std. Deviation & Std. Error Mean & Nilai p \\
\hline Pair 1 & Pretesperlakuan & 51.2000 & 15 & 17.59139 & 4.54208 & 0.001 \\
& Postesperlakuan & 92.8667 & 15 & 7.70776 & 1.99013 & \\
\hline & & \multicolumn{5}{c}{ Paired Samples Statistics } \\
\hline & & Mean & N & Std. Deviation & Std. Error Mean & Nilai p \\
\hline Pair 1 & Prekontrol & 54.0000 & 15 & 16.52703 & 4.26726 & 0.164 \\
& Postkontrol & 54.6667 & 15 & 16.44761 & 4.24675 & \\
\hline
\end{tabular}

Tabel 2 menunjukkan bahwa rata-rata nilai keterampilan ibu menyusui sebelum perlakuan rata-rata kategori kurang (nilai rata-rata 51- 54) dan meningkat setelah di berikan perlakuan dengan rata-rata nilai 92 (kategori baik) pada kelompok perlakuan dan 54 (kategori kurang) pada kelompok kontrol.

\section{PEMBAHASAN}

1. Keterampilan ibu dalam tehnik menyusui sebelum dan setelah diberikan pendekatan Supportive Educative (bimbingan dan pengajaran) pada kelompok perlakuan dan kelompok kontrol di PKM Karang Taliwang Mataram.

Hasil penelitian menunjukkan bahwa dari hasil uji Paired $\mathrm{t}$ Test diperolah nilai $\mathrm{P}$ $(0,001)<0,05$ terdapat perbedaan keterampilan menyusui responden sebelum dan setelah diberikan pendekatan Supportive Educative (bimbingan dan pengajaran) dibandingkan dengan kelompok kontrol didapatkan nilai p $(0,164)>0,05$ bahwa tidak terdapat perbedaan signifikan perawatan diri responden pada saat pre dan post test pada kelompok kontrol. Peningkatan kemandirian yang tejadi pada kelompok perlakuan dapat terjadi karena kegiatan bimbingan dan pengajaran ini kontak antara klien dan petugas lebih intensif dan setiap masalah yang dihadapi oleh klien dapat dikoreksi dan dibantu penyelesaiannya. Akhirnya klien akan dengan sukarela, 
berdasarkan kesadaran, dan penuh pengertian akan menerima perilaku tersebut sehingga dapat meningkatkan kesehatan atau kemandiriannya, dasar digunakannya pendekatan individu ini karena setiap individu mempunyai masalah atau alasan yang berbeda-beda sehubungan dengan penerimaan atau perilaku baru tersebut (Notoatmodjo, 2010). Menurut Orem dalam George (1995) memberikan bimbingan dan pengajaran serta memfasilitasi kemampuan klien dapat memenuhi kebutuhan secara mandiri pasien.

Menurut Tamsari (2007) juga menyatakan bimbingan dan pengajaran diselenggarakan untuk membantu klien dan keluarga mengembangkan kemampuan merawat diri, baik pada dimensi pengetahuan, sikap, maupun perilaku yang dapat memaksimalkan hidupnya. Menurut teorinya Green dalam Notoatmodjo (2010) perubahan perilaku dipengaruhi oleh faktor ekternal lain yaitu tradisi dan kepercayaan. Dari hasil wawancara dari beberapa responden yang memiliki keterampilan didapatkan bahwa dalam melakukan pencegahan agar tidak mengalami gangguan dalam proses menyusui mereka mengatakan mendapatkan informasi dari petugas kesehatan agar segera menyusui agar tidak menyebabkan bendungan ASI setelah bayi di lahirkan, menyusui yang sering agar tidak bengkak. Hal ini sangat mendukung terjadinya perubahan perilaku pada responden. Pengalaman belajar misalnya dalam mengikuti berbagai kegiatan dalam bentuk penyuluhan-penyuluhan yang salah satunya berisi tentang keterampilan menyusui yang berikan oleh tenaga kesehatan ataupun yang diperoleh melalui media akan dapat memberikan pengetahuan, informasi dan keterampilan profesional serta pengalaman belajar sehingga ini akan dapat mengembangkan kemampuan dalam mengambil keputusan.

Penelitian yang dilakukan Beger et al (2006) menunjukkan hasil Ibu dan perawat sepakat bahwa topik yang terkait dengan kebutuhan kesehatan fisik yang paling penting dan pengajaran individu dinilai paling efektif oleh kedua kelompok. Dan penggunaan media audiovisual dinilai kurang efektif. Menurut (Ruchala et al, 2000) persepsi tentang topik pengajaran yang paling penting menurut ibu nifas pada masa postpartum yaitu prioritas pengajaran pada perawatan diri (keterampilan menyusui), sehingga dapat disimpulkan bahwa terdapat terdapat perbedaan dalam Meningkatkan Keterampilan Ibu terhadap teknik menyusui bayi. Perubahan keterampilan ini terjadi karena responden telah diberikan pembelajaran tentang tehnik menyusui.

Saat melakukan teknik menyusui apabila Areola payudara sedapat mungkin semuanya masuk ke dalam mulut bayi, tetapi hal ini tidak mungkin dilakukan pada ibu yang areola payudaranya besar. Dengan tekanan bibir dan gerakan rahang secara berirama, maka gusi akan menjepit areola payudara, sehingga air susu akan keluar dari puting susu. Cara yang dilakukan oleh bayi ini tidak akan menimbulkan cedera pada puting susu (Bahiatun, 2005).

Peningkatan keterampilan ibu menyusui mencerminkan adanya peningkatan tingkat pengetahun dan keterampilan ibu menyusui bayi dari kurang baik menjadi baik. Dalam hal ini, aplikasi model Orem (supportive Edukative) dilakukan 2-3 kali agar mendapatkan peningkatan keterampilan yang bermakna. Keterampilan teknik menyusui responden setelah pelaksanaan 
pendekatan supportive edukative didapatkan hasil yang berbeda. keterampilan ibu dalam teknik menyusui bayi setelah Aplikasi model orem (Supportive edukative) didapatkan 14 (87,5\%) responden yang bayinya puas dan tenang pada akhir menyusui. Hasil ini di dapatkan karena wawasan pengetahuan ibu tetang teknik menyusui semakin bertambah dan dapat melakukan teknik menyusui sesuai dengan prosedur setelah di lakukan pembelajaran (Supportive edukative).

Menyusui tidak hanya memberikan manfaat bagi bayi, tetapi juga bagi ibu. Menurut Roesly (2003) Hormon Oksitosin yang dihasilkan melalui pembentukan ASI dapat mengerutkan otot polos dan pembuluh darah dirahim sehingga akan mempercepat pemberhentian pendarahan pada ibu setelah melahirkan. Roesly juga menyatakan bahwa menyusui dapat mencegah kehamilan dan mempercepat penurunan berat badan karena cadangan lemak akan terpakai untuk pembentukan ASI. Setelah itu menyusui dapat meningkatkan kepuasan ibu karena telah berhasil menjalankan kewajibannya sebagai ibu dan menjadi pengalaman unik bagi ibu saat bersentuhan dengan bayinya waktu menyusui.

Posisi menyusui harus senyaman mungkin, dapat dengan posisi berbaring atau duduk. Posisi yang kurang tepat akan menghasilkan perlekatan yang tidak baik. Posisi dasar menyusui terdiri dari posisi badan ibu, posisi badan bayi, serta posisi mulut bayi dan payudara ibu. Posisi badan ibu saat menyusui dapat dalam posisi duduk, tidur telentang atau posisi tidur miring. Saat menyusui, bayi harus disanggah sehingga kepala lurus menghadap payudara dengan hidung menghadap ke puting dan badan bayi menempel dengan badan ibu (sanggahan bukan hanya pada bahu dan leher). Sentuh bibir bawah bayi dengan puting, tunggu sampai mulut bayi terbuka lebar dan secepatnya dekatkan bayi ke payudara dengan cara menekan punggung dan bahu bayi (bukan kepala bayi). Arahkan puting susu ke atas, lalu masukkan ke mulut bayi dengan cara menyusuri langit-langitnya. Masukkan payudara ibu sebanyak mungkin ke mulut bayi sehingga hanya sedikit bagian areola bawah yang terlihat dibanding aerola bagian atas. Bibir bayi akan memutar keluar, dagu bayi menempel pada payudara dan puting, susu terlipat di bawah bibir atas bayi (Bahitun 2005).

Selain itu, proses menyusui yang benar, bayi akan mendapatkan perkembangan jasmani, emosi maupun spiritual yang baik dalam kehidupannya (Saleha, 2009). Masa laktasi mempunyai tujuan meningkatkan pemberian ASI eksklusif dan meneruskan pemberian ASI sampai anak umur 2 tahun secara baik dan benar serta anak mendapatkan kekebalan tubuh secara alami (Ambarwati, dkk.2009). Menyusui merupakan proses yang cukup kompleks. Pada masa ini, ibu dan anak membentuk satu ikatan yang kuat (IDAI, 2008).

Untuk melakukan teknik menyusui bayi tidak diperlukan biaya yang besar, namun dalam melakukan teknik menyusui ini perlu diperhatikan berbagai hal agar teknik menyusui bayi yang dilakukan tidak sia-sia. Teknik menyusui bayi merupakan cara memberikan ASI kepada bayi dengan perlekatan dan posisi ibu dan bayi dengan benar. Menyusui adalah suatu proses yang terjadi secara alami. Jadi, jarang sekali ada ibu yang gagal atau tidak mampu menyusui bayinya. 
Meskipun demikian, menyusui juga perlu dipelajari, terutama oleh ibu yang baru pertama kali memiliki anak agar tahu cara menyusui yang benar. Makin dini bayi disusui, maka kian cepat dan lancar proses menyusui (Bahiatun, 2005).

Hal diatas bisa juga dipengaruhi oleh pendidikan. Pada tabel 5.1 terlihat sebagian besar ibu mengenyam pendidikan SMA/PT. Seseorang yang berpendidikan tinggi akan memberikan respon yang lebih rasional dari pada mereka yang berpendidikan rendah atau sedang. Dengan pendidikan yang rendah maka dapat berpengaruh pada tingkat pengetahuan ibu. Pada ibu yang berpendidikan tinggi cenderung mencari informasi tentang teknik menyusui yang benar (Notoatmodjo, 2003).

Pendidikan yang rendah baik secara formal maupun informal menyebabkan ibu kurang memahami tentang teknik menyusui yang benar. Teknik menyusui merupakan salah satu faktor yang mempengaruhi produksi ASI dimana bila teknik menyusui tidak benar, dapat menyebabkan puting susu lecet dan menjadikan ibu enggan menyusui sehingga bayi tersebut jarang menyusu. Enggan menyusu akan berakibat kurang baik, karena isapan bayi sangat berpengaruh pada rangsangan produksi ASI selanjutnya. Namun sering kali ibu- ibu kurang mendpatkan informasi tentang manfaat ASI dan tentang menyusui yang benar (Roesli, 2005).

2. Perubahan Keterampilan menyusui pre dan post test pada kelompok perlakuan dan kelompok kontrol Hasil penelitian tentang Aplikasi Model Orem Dalam Meningkatkan Keterampilan Dalam Tehnik Menyusui di PKM Karang Taliwang - Mataram NTB

Pada pre test kelompok perlakuan, keterampilan ibu dalam menyusui adalah kurang dan diperoleh rata-rata peningkatan nilai sebanyak $(41,6)$ pada post test sehingga rata-rata responden masuk dalam kategori keterampilan baik atau kemampuan keterampilannya meningkat setelah dilakukan pembelajaran dengan aplikasi model Orem. Sedangkan keterampilan responden terbanyak pada kelompok kontrol pada saat pre test adalah kurang dan diperoleh rata-rata peningkatan nilai sebanyak 0.6 dan nilai yang diperoleh masih dalam kategori kurang dalam keterampilan menyusui.

Hasil uji statistik Independen $t$ test menunjukkan nilai $\mathrm{p}(0,000)<0,05$ yang berarti ada perbedaan signifikan antara keterampilan menyusui pada kelompok perlakuan dan pada kelompok kontrol. Sebelum dilaksanakan pendekatan supportive edukative, di peroleh data yaitu dari 15 responden ada 2 responden yang memiliki keterampilan tehnik menyusui yang benar baik pada kelompok perlakuan maupun kontrol, Ini berarti hanya sedikit responden yang menyusui bayi dengan teknik menyusui bayi yang benar.

Keluhan dan kesulitan saat menyusui sering muncul, apalagi jika ibu adalah pengalaman pertama. Mulai dari ASI tidak keluar dengan lancar, puting payudara luka, hingga si kecil rewel karena belum bisa menyusui dengan benar. Kesulitan menyusui biasanya terjadi ketika ibu baru melahirkan anak pertama. Selain ini merupakan pengalaman baru, biasanya ibu juga masih 
canggung dalam menggendong si kecil, atau bahkan mudah panik jika dia menangis keras karena sesuatu hal. Sebaliknya bayi baru lahir harus belajar cara menyusui yang benar (Supriyadi, 2002). Selain dari faktor internal ada juga faktor eksternal yaitu Ibu kurang mendapatkan informasi dan pengalaman yang baik dari lingkungan dalam maupun luar. Informasi dari keluarga atau petugas yang kurang dan atau dari ibu nifasnya sendiri yang belum mau memulai memberikan ASI di karenakan ASI yang belum keluar, sehingga informasi yang di berikan di awal sangat di butuhkan agar ibu nifas memberikan ASI nya segera setelah melahirkan agar bisa mencegah payudara bengkak dan ASI lancar karna pengaruh oksitosin terhadap isapan bayi.

Perubahan kemampuan keterampilan ibu dalam menyusui setelah dilakukan pembelajaran pada kelompok perlakuan beberapa responden mengakui lebih cepat memahami karena di bimbing, di ajarkan dan lansung dievaluasi oleh peneliti sehingga perubahan kemampuan responden sangat tampak signifikan, sedangkan pada kelompok control tidak ada perubahan kemampuan dalam keterampilan menyusuinya di karenakan beberapa responden mengaku masih takut untuk menyusui bayinya dan menganggap ASI nya tidak bisa keluar. Petugas kesehatan khususnya di PKM Karang Taliwang biasanya memberikan pembelajaran tentang tehnik menyusui pada ibu-ibu post partum ketika control pada hari ke tiga dan beberapa responden mengaku mendapatkan pembelajaran tentang tehnik menyusi tersebut biasanya dari keluarganya atau kerabat dekatnya.

\section{Identifikasi Peningkatan Berat Badan Bayi}

Hasil penelitian menunjukkan bahwa dari hasil uji Mann-Whitney Test diperolah nilai $\mathrm{p}$ $(0,240)<0,05$ tidak terdapat perbedaan peningkatan BB bayi responden sebelum dan setelah diberikan pendekatan Supportive Educative (bimbingan dan pengajaran) pada kelompok perlakuan maupun Kontrol. Berbagai studi dan pengamatan menunjukkan bahwa dewasa ini terdapat kecenderungan penurunan penggunaan ASI dan mempergunakan pemberian ASI dengan susu fomula di masyarakat. Dengan kenaikan tingkat partisipasi wanita dalam angkatan kerja dan peningkatan sarana komunikasi dan transportasi yang memudahkan periklanan susu buatan serta luasnya distribusi susu buatan terdapat kecenderungan menurunnya kesediaan menyusui maupun lamanya menyusui baik dipedesaan dan diperkotaan.

Menurunnya jumlah ibu yang menyusui sendiri bayinya pada mulanya terdapat pada kelompok ibu dikota-kota terutama pada keluarga berpenghasilan cukup yang kemudian menjalar sampai ke desa-desa. Meskipun menyadari pentingnya pemberian ASI tetapi budaya modern dan kekuatan ekonomiyang semakin meningkat telah mendesak para ibu untuk segera menyapih anaknya dan memilih air susu buatan sebagai jalan keluarnya. Meningkatnya lama pemberian ASI dan semakin meningkatnya pemberian susu botol menyebabkan kerawanan gizi pada bayi dan balita. Pada acara peringatan hari ibu ke-62 di Jakarta 22 Desember 1990 telah dicanangkan gerakan nasional peningkatan penggunaan ASI oleh mantan Presiden Soeharto. Dianjurkan agar 
ibu-ibu paling tidak agar menyusui bayinya selam 4-6 bulan dan juga bahkan agar kaumibu memeloporinya. Perlunya pemberian ASI pada anak sudah menjadi masalah nasional dan intemasional mengingat eratnya hubungannya dengan gizi anak (Siregar,2004).

Menurut The World Alliance for Breastfeeding Action (WABA), untuk keberhasilan menyusui seorang ibu perlu dukungan dari berbagai pihak, yaitu dari keluarga, teman, masyarakat dan pemerintah. Adanya ukungan dari berbagai pihak tersebut diharapkan dapat mengurangi berbagai tantangan yang dihadapi ibu menyusui, seperti mengatasi kurangnya informasi, bermacam-macam situasi emergency, dan yang paling penting adalah mengatasi keraguan akan kemampuannya untuk dapat menyusui bayinya. Hal tersebut menunjukkan bahwa kegagalan pemberian ASI dapat disebabkan oleh bermacam faktor yaitu faktor internal maupun eksternal. Faktor internal yaitu dari dalam diri ibu antara lain Pengalaman menyusui sebelumnya yang mengalami kesulitan dalam menyusui, pendidikan yang rendah serta ibu sebagai status pekerja Sedangkan faktor eksternal antara lain peran ayah dalam membantu kesulitan-kesulitan menyusui, faktor bayi misalnya berat badan turun, bayi kelihatan masih lapar,atau menderita diare, sehingga ibu menganggap produksi ASInya masih kurang/tidak sesuai maka pemberian susu formula/makanan lain menjadi alternatif pemecahannya serta faktor sosial budaya dalam masyarakat seperti kebiasaan memberi air puth dan cairan lain seperti teh, air manis, dan jus kepada bayi dalam bulan bulan pertama, hal ini umum dilakukan di banyak negara.Riset yang dilakukan di pinggiran kota Lima, Peru menunjukkan bahwa $83 \%$ bayi menerima air putih dan teh dalam bulan pertama. Penelitian di masyarakat Gambia, Filipina, Mesir, dan Guatemala melaporkan bahwa lebih dari 60\% bayi baru lahir diberi air manis (Hikmawati,2008).

Berdasarkan wawancara dan Pengamatan yang dilakukan peneliti dari beberapa resonden yang tidak mengalami peningkatan Berat Badan bayinya sebagian besar di sebabkan oleh karna factor ibu yang malas menyusui bayinya dan atau bayi yang malas menyusu, akan tetapi persentasi peningkatan (BB Normal) berat badan bayi pada responden yang di berikan pembelajaran lebih tinggi (13 orang / 80\%) di banding kelompok control (9 orang/ 60\%).

\section{KESIMPULAN DAN SARAN}

Dari hasil penelitian dan pembahasan penelitian dapat disimpulkan bahwa terdapat perbedaan keterampilan responden sebelum dan setelah diberikan pendekatan Supportive Educative (bimbingan dan pengajaran). Namun demikian tidak ada perbedaan peningkatan Berat Badan bayi pada kelompok perlakuan maupun kontrol. Bagi puskesmas, hasil penelitian ini dapat digunakan sebagai bahan masukan dalam metode melaksanakan pendidikan kesehatan untuk meningkatka keterampilan ibu tentang teknik menyusui bayi pada saat setelah melahirkan dan di evaluasi keterampilannya pada saat kunjungan ibu nifas setelah melahirkan sehingga bisa meningkatkan kemampuan ibu menyusui. Ibu 
hamil dapat melakukan keterampilan menyusui bayi dengan teknik yang benar sebagai salah satu alternatif dalam memberikan ASI esklusif sehingga bayi menjadi sehat. Penelitian selanjutnya sebaiknya menggunakan sampel yang lebih banyak dan mengidentifikasi pula faktor-faktor yang mempengaruhi kenaikan BB bayi selain pemberian ASI.

\section{DAFTAR PUSTAKA}

Almatsier, S, 2004. Prinsip Dasar Ilmu Gizi. PT. Gramedia Pustaka Umum. Jakarta. Arikunto, S, 2006 Alligood, MR(2006) Nursing Theories and Their Work $6^{\text {th }}$ Ed. Mosby. St. Louis Missouri

Badan Penelitian dan Pengembangan Kesehatan, (2010), Riset Kesehatan Dasar (Riskesdas 2010), Kementerian Kesehatan Republik Indonesia, Jakarta

Bobak, Lowdermilk, Jensen. (2004). Buku Ajar Keperawatan Maternitas, Edisi 4, Jakarta: EGC.

Begel, Cynthia A, Loveland Cook (2006), Postpartum Teaching Priorities : the Viewpoints of Nurses and Mother, Journal of Obstetric, Gynecologic, \& Neonatal Nursing Volume 27, Issue 2, pages $161-168$.

Direktorat Kesehatan Anak Khusus (2010) Panduan Pelayanan Kesehatan Bayi Baru Lahir Berbasis Perlindungan Anak http://www.gizikia.depkes.go.id di unduh tanggal 7 April 2016

Damai Yanti, Sundawati (2011), Asuhan Kebidanan Masa Nifas. Bandung : Refika aditama

Diana Nur Afifah (2007) Faktor Yang Berperan Dalam Kegagalan Praktik Pemberian Asi Eksklusif (Studi Kualitatif di Kecamatan Tembalang, Kota Semarang Tahun 2007)

Isna Hikmawati, 2008 Faktor - Faktor Risiko Kegagalan Pemberian Asi Selama Dua Bulan

(Studi Kasus Pada Bayi Umur 3-6 Bulan Di Kabupaten Banyumas) Tesis Magister Epidemiologi Program Pascasarjana Universitas Diponegoro Semarang

Maryunani, (2009). Asuhan Pada Ibu Dalam Masa Nifas. Jakarta: Trans Info Media.

Nursalam, 2008, Konsep \& Penerapan Metodelogi Penelitian Ilmu Keperawatan Pedoman Skripsi, Tesis dan Instrumen Penelitian Keperawatan, Salemba Medika, Jakarta.

Notoatmojo, (2010). Imu Perilaku Kesehatan. Jakarta: Rineka Cipta

Ruchala, Patsy L., Teaching new mother : Priorities of nurses and postpartum women, Journal of Gynecologic, \& Neonatal Nursing Volume 29, Issue 3, pages 265-273, May 2000

Rizka Yulianti Rahayu, Sari Sudarmiati (2012) Pengetahuan Ibu Primipara Tentang Faktor-Faktor Yang Dapat Mempengaruhi Produksi Asi, Jurnal Nursing Studies, Volume 1, Nomor 1 Tahun 2012, Halaman 108 - 115 O : http://ejournal-s1.undip.ac.id/index.php/jnursing di unduh tanggal 5 April 2016

Arifin Siregar, 2004 Faktor - Faktor Yang Mempengaruhi Pemberian Asi Oleh Ibu Melahirkan. Bagian Gizi Kesehatan Masyarakat Fakultas Kesehatan Masyarakat Digital Library Universitas Sumatera Utara (USU) 